\title{
浅析影响水稻高产栽培的主要因素及其策略
}

\author{
于淼 \\ 黑龙江省八五七农场 \\ DOI:10.32629/as.v2i4.1629
}

[摘 要] 目前受农村劳动力转移、劳动力老龄化、水稻插种成本提升多种因素影响,对于目前水稻栽培提出了更高要求,因此 更加需要科学的栽培技术以及机械化设备, 实现水稻高产。基于此, 本文概述了水稻,对影响水稻高产的主要因素及其策略进行 了探讨分析,旨在提高水稻产量。

[关键词] 水稻; 高产；影响因素；栽培; 策略

随着水稻种植业的不断发展, 提升了水稻高产优质栽培 技术, 并且目前水稻栽培开始向品种多样化、种植规范化以 及管理科学化方向发展。因此为了实现水稻高产, 需要通过 创新水稻种植技术、严格优良水稻品种的选择以及水稻病虫 害防治等策略, 去更新目前的水稻种植技术与种植手段, 不 断提升水稻种植产量与种植质量, 从而促进我国农业的可持 续化、科技化方向发展。

\section{1 水稻的概述}

水稻是一年生禾本科植物, 高约 1.2 米, 叶长而扁, 圆锥 花序由许多小穗组成。所结子实即稻谷, 去壳后称大米或米。 水稻可以分为籼稻和粳稻、早稻和中晚稻、糯稻和非糯稻。 水稻除可食用外, 还可以酿酒、制作糖工业原料, 稻壳、稻秆 也有很多用处。水稻属于禾本科稻属, 是一个极其古老的作 物。据考古发现, 水稻在我国的种植历史至少有 7000 年左右。 世界上的栽培稻有 2 个种即亚洲栽培稻和非洲栽培稻。其中 亚洲栽培稻种植面积大, 遍布全球各稻区, 所以称之为普通 栽培稻。中国栽培稻可分成籼、粳两个亚种, 并根据品种的 温光反应, 需水量及胚乳淀粉特性等在籼、粳亚种下又分为 早、晚, 水、陆, 粘 (非糯) 、糯等不同类型。

\section{2 影响水稻高产的主要因素分析}

结合笔者实践工作经验,认为影响水稻高产的因素主要有:

2. 1 育种因素

水稻栽培的基础便是育种, 种子直接影响着水稻的生长 状况与产量水平。为了进一步提升水稻的产量, 相关工作人 员必须做好育种工作。但实际调查发现, 当前水稻育种工作 存在很多亟待解决的问题, 且水稻育种系统也存在很多不完 善的地方。比如科研力量分散、育种效率低以及不重视资源 的引进等。同时, 水稻育种的集中化程度较低, 很多地方属于 种植者自行育种, 由于缺乏专业知识与设备, 以致育种水平 较低。

\section{2 土壤因素}

种植土壤直接影响着水稻的生长状况, 现在我国水稻属 于连续多年种植, 对土壤的消耗较大。同时, 为了提高水稻的 产量, 很多种植人员加大了化肥使用量, 并使用了不合理的 种植技术, 以致土壤有机碳储量不断下降, 土壤板结, 直接影
响了水稻的可持续发展。

\section{3生产条件因素}

水稻不同于一般旱田作物, 其对栽培技术的要求较高, 不但需要健全的设施与配套设备, 且还需要良种与高产栽培 技术。当前我国土地平整度较差, 基础设施比较落后, 且缺乏 标准性。为了实现水稻高产, 技术人员应不断提升种植条件 水平, 完善种植设施, 实现水稻栽培的标准化。

\section{3 水稻高产栽培策略的分析}

3. 1 积极创新水稻高产栽培技术

高产栽培技术应用过程中, 最重要的就是加强高产栽培 技术的创新与应用, 从而实现高产栽培技术的有效继承。注 重农机与农业的有效结合。在水稻种植过程中, 应该加强规 范化栽培的推广, 精确定量栽培。水稻强化栽培作为一项增 产技术, 它具有相当大的种植优势, 如能够最大限度地利用 周围线的大小, 提高光能利用率, 还加强个体和群体的副作 用, 并发挥其优势, 提高产量。只有将优良的品种, 良好的方 法, 环境优化与生产投入相结合, 才能实现高产和高质量的 目的。对于栽培技术的应用, 基层人民需要选择水稻品种, 以促进优良品种的生产潜力。在水稻精确定量栽培技术的应 用中, 对密植种标准有明确的定义, 以确保水稻能够在半透 明光的基础上最大化生产。例如, 中国农业部开展了一系列 优质绿色高产高效全区推广项目。在第一季稻米收获后, 再 生稻示范区采用高产高效的技术, 如及时补液, 种子施肥和 秸秆覆盖。促进了再生稻的生产, 提高了水稻的种植效率。 因此, 基层可以在参考区的栽培结果的前提下提高种植水平 和种植技术。在水肥管理中, 我们也必须注重技术创新。目 前, 它一般是土壤测试和配方施肥的方法。有必要根据水稻 品种和土壤肥力水平配制肥料。种植者需要遵循技术人员的 管理和建议。肥料的比例。一般来说, 施肥是以基肥为基础, 以追肥为辅。通过增加氮, 磷和钾肥的施用, 改善了水稻生 产和育肥。一般来说, 氮肥, 磷肥和钾肥的比例为 $14: 7: 6$, 良 好, 基层应结合技术人员的指导, 在规定的时间内施肥, 如氮 肥和穗肥, 移栽后 10 天内。个别地区在水稻高产优质栽培技 术创新的过程之中, 也搭建了耕地地力监测和测土配方技术 体系, 应用了绿肥还田、有机肥与无机肥有机结合的施肥形 
式, 这样一来不仅仅能够提升水稻种植的质量, 也大大地改 良了土壤内部成分, 提升了区域内部土壤的平均有机质。一 线工人应掌握水稻不同生长阶段的发育特征。分藥期, 长期 生育期和灌浆期均具有不同时期的管理特征。以分藥阶段的 管理为例。湿式和干式灌溉方法使用施肥来促进分菜。在长 期收益阶段, 必须注意土壤含水量的维持, 并且水含量可以 控制在 $80 \%$ 至 $90 \%$ 以满足标准。在结果期的管理中, 我们必 须注意灌溉的间歇性, 以确保生产的每个方面都能安全有效 地进行。

3. 2 严格优良水稻品种的选择

随着水稻品种的不断发展, 水稻种植需要结合实际种植 条件和国内宏观推广品种选择优质水稻品种。一些高质量, 早熟和高产的品种在示范和推广过程中能够实现平均增产。 例如, 在武育粳 3 号的定向改良后, 选择并维持了 4 个具有综 合性状的新品系。吴玉疍的优良特性, 也可以提高他们的抗 病能力, 他们的整体总产量和单一产量也在迅速增加。水稻 种植者应加强对水稻品种的了解, 并根据实际情况选择最适 合种植的水稻品种。

3. 3 强化水稻病虫害防治

目前水稻病虫害的防治也开始向绿化, 环保和高效转 变。目前, 在水稻病虫害防治领域, 一些地区采取了 “稻鸭养 殖” 的手段, 即共养鸭, 种植水稻, 利用鸭子。日常饲养活动, 减少病虫害技术, 彻底消除和控制害虫, 真正实现生态环境 的和谐建设和种植环境的保护。此外, 还可以使用相应的方
法, 例如昆虫诱捕器杀灭, 物理诱捕, 化学控制等。农药的使 用也鼓励使用高效和低毒的试剂。从而实现对水稻害虫的控 制。此外, 水稻病害的防治更加注重早期水稻的防治。收割 稻米后, 有必要及时耕种稻田。在冬季, 有必要加强对田间杂 草和周围杂草的消毒和清理, 及时打捞漂浮的菌核, 破坏病 虫害的越冬。遗址, 从而减少病虫害技术和病虫害发生的可 能性。根据目前高产栽培技术的指导, 在进行化学防治, 联合 防治, 选择高效, 低毒, 无残留农药进行防治时, 应集中水稻, 施用后, 需要在田间保持良好的水层, 厚度控制在 $5 \mathrm{~cm}$ 左右, 持续4d, 可达到预期的控制效果。另外, 针对经常发生的纹枯 病、白叶枯病、稻曲病要建立病害应急防治方案, 从而降低 影响范围与影响程度。

\section{4 结束语}

综上所述, 水稻高产栽培主要体现在种植方式、种植形 式与品种改良等方面上, 所以在水稻种植过程之中, 需要充 分明确影响水稻高产的主要因素, 通过采取相应的策略, 从 而提升水稻产量以及确保粮食安全。

\section{[参考文献]}

[1]王立国, 严宝林, 王井琴. 寒地有机水稻高产栽培综合 配套技术 $[J]$.农业与技术,2018(22): 141 .

[2]王朝晖.中国水稻高产栽培技术创新的探讨 [ J].农家 参谋,2018(16):50.

[3]韩成新.试析水稻种植技术的创新尝试[J].农业开发 与装备,2018(06):163. 